\title{
Scholarly Publishing, Freedom of Information and Academic Self-Determination: The UNAM-Elsevier Case
}

\author{
Ernesto Priego ${ }^{1}$, Erin McKiernan ${ }^{2}$, Alejandro Posada ${ }^{3}$, Ricardo Hartley ${ }^{4}$, Nuria Rodríguez \\ Ortega $^{5}$, Domenico Fiormonte ${ }^{6}$, Alex Gil ${ }^{7}$, Corina Logan ${ }^{8}$, Juan Pablo Alperin ${ }^{9}$, Ross \\ Mounce $^{10}$, Stephen J Eglen ${ }^{8}$, Ernesto Miranda Trigueros ${ }^{11}$, Stuart Lawson ${ }^{12}$, Laurent \\ Gatto $^{8}$, Adela Ramos ${ }^{13}$, and Natalia Pérez ${ }^{14}$ \\ ${ }^{1}$ City, University of London \\ ${ }^{2}$ Universidad Nacional Autónoma de México \\ ${ }^{3}$ Knowledge GAP Project \\ ${ }^{4}$ Universidad Central de Chile \\ ${ }^{5}$ University of Málaga \\ ${ }^{6}$ Roma Tre University \\ ${ }^{7}$ Columbia University \\ ${ }^{8}$ University of Cambridge \\ ${ }^{9}$ Simon Fraser University \\ ${ }^{10}$ University of Bath \\ ${ }^{11}$ Secretaría de Cultura Federal, México \\ ${ }^{12}$ Birkbeck, University of London \\ ${ }^{13}$ Pacific Lutheran University \\ ${ }^{14}$ University of Southern Califorinia
}

November 25, 2017

On February 1, 2015, the global information and analytics corporation Elsevier and the National Autonomous University of Mexico (UNAM) established the agreement UNAM-Elsevier contract DGAJ-DPI-39-081114241, which saw the transfer from UNAM to Elsevier for the "production and hosting, advertising and support" of 44 Mexican open access academic journals published by UNAM.

This article documents said contract and describes a Freedom of Information Request enquiring the total cost of the contract and its corresponding response. It also shares a series of considerations that, based on this case, can be helpful to other institutions that may face similar circumstances in the future. We conclude scholarly publishing and academic self-determination are interdependent and a crucial point of future debate for the future of University presses and Open Access worldwide.

\section{Introduction}

The intention of this output is to document and discuss publicly the agreement between the information and analytics global corporation Elsevier and the National Autonomous University of Mexico (UNAM) signed on 1 February 2015. 
The agreement, UNAM-Elsevier contract DGAJ-DPI-39-081114-241, saw the transfer of "production and hosting, advertising and support" of 44 UNAM-published academic open access journals to information and analytics global company Elsevier. A redacted PDF of a scanned copy of the contract document was leaked anonymously and made available on-line through an anonymous blog post (i1706406 2015). We became aware of the contract doing on-line research related to Elsevier on the open Web.

This output follows the previous publication, in Spanish, of "Revistas académicas de la UNAM entregadas a Elsevier/ScienceDirect" (Priego 2017) on 8 August 2017 on the Humanidades Digitales blog of the Mexican Digital Humanities Network (Red de Humanistas Digitales), and the main body of this output is the result of collaborative adaptation, revision and augmentation of the text that was collectively discussed and coauthored online as an open letter to the international academic community (Various 2017).

The collaborative work on the letter, which included English and Spanish versions, took place over a period of three months between august and october 2017 in direct collaboration with colleagues from UNAM who unfortunately, for different reasons, felt unable to sign the letter publicly. That original letter was first signed by 28 international academics from 8 different countries including Mexico. The letter is available publicly online and signatures can still be added at https://goo.gl/forms/ZL8QF3ZVT4p3KFNr2 (Various 2017).

We respect our colleagues' desire for anonymity and understand the pressures they are under. We are also fully aware that the majority of us who sign this output are academics based in institutions in the Global North and therefore not necessarily implicated in or directly affected by the contract in question.

\section{Context and Limitations}

We are acutely aware of the geopolitical inequalities in the production and assessment of academic knowledge (Fiormonte \& Priego 2016; Fiormonte 2017; Graham 2011). We are therefore particularly sensitive to the fact we are documenting this case from a position of relative academic privilege and geopolitical distance from the actual events. Indeed, rather than contributing to perpetuate the dominance of "North American and Western European perspectives" (Bosman et al 2017), the genealogy of this text reveals an attempt at contributing to the design of more transparent and open scholarly communication practices that can also "meaningfully be built for and by researchers in the global south" (Hathcock 2016).

In light of the above we openly declare the lack of more Mexico-based names in the byline of this output as a limitation. However, that we are in a position to publish this output can serve the purpose of documenting how commercial interests can potentially tamper with international academic freedom, promoting an atmosphere of disempowerment and fear if critical opinions or discontent are publicly voiced.

It appears to be common knowledge amongst colleagues associated with UNAM scholarly publishing that the contract in question "is about to end", as it was reported to us in personal correspondence. However, it is important to note that there is no public information about when the contract's end date exactly is nor what will happen to the journals under contract after the agreement ends.

Though we are aware that this output is being published belatedly as the contract is fait accompli, we would still like to document that transparency and sustainability in scholarly publishing are important considerations that should be publicly discussed with an open and international scope. For insiders in Latin American scholarly communications, this contract is not news. However, as members of international scholarly communities and therefore participant stakeholders in the scholarly commons, we wish to document this case in order to foster wider awareness of current practices in scholarly publishing worldwide and foster future debates on good practices in the transition to more widespread, fair Open Access.

The latest available figures indicate that UNAM has 4,598 registered researchers, with $30 \%$ of all articles published by Mexican researchers having UNAM affiliations; in 2016 alone UNAM researchers published 5, 643 articles registered in International Science Indicators (UNAM 2017; UNAM 2017). Since UNAM is a leading educational Latin American institution whose academics and alumni are members of international 
scholarly communities around the world, and since Elsevier and its parent companies continue to dominate in the global scholarly communications landscape (Schmitt 2015; Eve 2016) we believe it is important to document and discuss this case in order to establish further knowledge exchange with our colleagues based in Mexico and to leave a precedent in the scholarly record that may hopefully help other institutions facing similar situations.

\section{The Data}

The titles of the 44 UNAM Journals under contract with Elsevier appear in the UNAM-Elsevier contract DGAJ-DPI-39-081114-241. We extracted the data from the PDF and searched for each title manually on https://www.elsevier.com/catalog?producttype=journal to confirm which journals had a dedicated publicly-available URL on https://www. journals. elsevier.com/.

We then created a spreadsheet including the journal consignation number and title according to the contract (columns A and B) and added the corresponding URLs on column C, as shown below (Table 1).

List of UNAM journals under contract with Elsevier according to source document DGAJDPI-39-081114-241

\begin{tabular}{ll}
\hline Cons. & Title \\
\hline 1 & Acta de Investigación Psicológica \\
2 & Acta Poética \\
3 & Acta Sociológica \\
4 & Anales de Antropología \\
5 & Anuario de Letras, Lingüística y Filología \\
6 & Anuario Mexicano de Derecho Internacional \\
7 & Atmósfera \\
8 & Boletín Mexicano de Derecho Comparado \\
9 & Contaduría y Administración \\
10 & Cuestiones Constitucionales \\
11 & Economía Informa \\
12 & Economía UNAM \\
13 & Educación Química \\
14 & Enfermería Universitaria \\
15 & Estudios de Cultura Maya \\
16 & Estudios de Historia Moderna y Contemporánea de México \\
17 & Estudios de Historia Novohispana \\
18 & Estudios Políticos \\
19 & Geofísica Internacional \\
20 & Ingeniería, Investigación y Tecnología \\
21 & Investigación Bibliotecológica: bibliometría, archivonomía e información \\
22 & Investigación Económica \\
23 & Investigación en Educación Médica \\
24 & Investigaciones Geográficas, Boletín del Instituto de Geografía \\
25 & Journal of Applied Research and Technology, JART \\
26 & Journal of Behavior, Health and Social Issues \\
27 & Latinoamérica, Revista de Estudios Latinoamericanos \\
28 & Literatura Mexicana \\
&
\end{tabular}

Elsevier URL [This data not incluc http://www. journals.elsevier.com/ http://www. journals.elsevier.com/ http://www. journals . elsevier.com/s http://www.journals.elsevier.com/ http://www. journals.elsevier.com/ http://www. journals.elsevier.com/ http://www.journals.elsevier.com/ http://www. journals.elsevier.com/ http://www. journals.elsevier.com/ http://www.journals.elsevier.com/ http://www. journals.elsevier.com/ http://www. journals.elsevier.com/ http://www. journals.elsevier.com/ http://www . journals . elsevier.com/ http://www . journals . elsevier.com/ http://www . journals. elsevier. com/ http://www. journals.elsevier.com/ http://www. journals.elsevier.com/ http://www. journals.elsevier.com/ http://www . journals . elsevier.com/: http://www . journals . elsevier. com/ http://www . journals . elsevier.com/ http://www . journals . elsevier. com/ http://www . journals. elsevier.com/ http://www . journals.elsevier.com/. http://www. journals.elsevier.com/. http://www . journals . elsevier. com/http://www. journals.elsevier.com/ 


\begin{tabular}{|c|c|c|}
\hline Cons. & Title & Elsevier URL [This data not incluc \\
\hline 29 & Mexican Law Review & http://www.journals.elsevier.com/1 \\
\hline 30 & Norteamérica, Revista Académica del CISAN-UNAM & http://www.journals.elsevier.com/ \\
\hline 31 & Nova-Tellus & Not found \\
\hline 32 & Península & http://www.journals.elsevier.com/ \\
\hline 33 & Perfiles Educativos & http://www.journals.elsevier.com/ \\
\hline 34 & Problemas del Desarrollo & http://www.journals.elsevier.com/ \\
\hline 35 & Revista Iberoamericana de Educación Superior & http://www.journals.elsevier.com/: \\
\hline 36 & Revista Latinoamericana de Derecho Social & http://www.journals.elsevier.com/: \\
\hline 37 & Revista Mexicana de Biodiversidad & http://www.journals.elsevier.com \\
\hline 38 & Revista Mexicana de Ciencias Políticas y Sociales & http://www.journals.elsevier.com \\
\hline 39 & Revista Mexicana de Opinión Publica & http://www.journals.elsevier.con \\
\hline 40 & Revista Mexicana de Ortodoncia & http://www.journals.elsevier.con \\
\hline 41 & Revista Mexicana de Trastornos Alimentarios & http://www.journals.elsevier.con \\
\hline 42 & Revista Odontológica Mexicana & http://www.journals.elsevier.con \\
\hline 43 & Tip. Revista Especializada en Ciencias Químico-Biológicas & http://www.journals.elsevier.con \\
\hline 44 & Veterinaria México OA & Not found \\
\hline
\end{tabular}

Table 1. List of UNAM Journals Under Contract with Elsevier.

On the complete spreadsheet shared on figshare (Priego 2017a) we also included additional data obtained from checking each URL manually. On column D we indicated if by January 2016 (version 1) the content on that URL was live or not. By searching for the journal's name as indicated in the cotract two journal sites were not found to exist. We checked each URL again on August 2017 and updated the spreadsheet, adding that data on column E (version 2), as it was important to follow-up and confirm the status of the journals under contract (there had been no changes on the live status of the journal sites). On column $\mathrm{F}$ we noted if the page on each journal's respective Web page, when they existed, contained an article listing or not. We manually visited each journal's URL and followed the links and noted what happened after clicking on the journal link on the 'Elsevier hub' on column G. On a second sheet we included a summary of the contract's key information across ten columns.

\section{Public Information Request and Corresponding Response}

On 28 July 2016, one of the authors of this document submitted a public information request (equivalent to a 'Freedom of Information Request') to the Mexican National Transparency Platform of the "National Transparency System". The request received folio number 6440000038816. The request was for the complete document of the UNAM-Elsevier contract DGAJ-DPI-39-081114-241 be made available to the public including any amount the UNAM may have had to pay Elsevier.

Almost a year later, we discovered that the UNAM Transparency Committee had indeed issued a response. The Resolution CTR / 49/2016 dated 29 August 2016 (Comité de Transparencia de la UNAM 2016) stated that, despite acknowledging and confirming the "public nature" of the information requested, the amount payable to Elsevier "is considered to be reserved" information and therefore cannot be made public for a period of 5 years from the date of the resolution or until the contract ceases to be in force (Priego 2017b). Crucially, when exactly the contract expires was also ruled to be "reserved information", and therefore the date cannot be made known to the public either.

We believe that such a decision privileges contractual terms and protects the financial interests of a for-profit corporation at the expense of the right of access to public information with a detriment to the interests of the UNAM community and affiliates in the country. 


\section{Considerations}

International academic communities deserve to be informed about the costs of academic publishing. We argue that communities should be consulted and informed more openly and transparently about the causes, conditions and consequences of publishing contracts like this one. Given UNAM's national public nature and that the journals under contract were all already published open access by the University, this agreement delivers a significant portion of the public and cultural heritage of the University to a for-profit transnational corporation (Posada \& Chen 2017).

Considering UNAM's particular case, it should also be noted that Mexico's Open Access Law Initiative (Herrero Anzaldo 2013) had offered public funding for the "creation, adaptation or maintenance of open access publishing platforms"; said initiative became law on 20 May 2014 (Rangel 2014). For perspective, as we have documented the Elsevier-UNAM contract included 44 UNAM journals; REDALyC indexes 46 UNAM journals (REDALyC n.d.).

Given the context we therefore wish to share the following considerations:

- It is important to reconsider the primacy of the right to access public information on contractual terms imposed by transnational for-profit corporations to publicly financed institutions (Lawson 2015; Lawson \& Meghreblian 2014).

- The reasons why a publicly-financed institution considers necessary to request scholarly publishing services from a for-profit third party should have been disclosed widely and transparently. In this case, it is essential to emphasise that Latin America is one of the leading regions in the world in regards to open access scientific journal publishing (Alperin 2015; UNESCO 2017).

- It is good practice for publicly-financed institutions to make bidding processes details public, disseminating them widely, and including what other alternatives were considered prior to selecting a particular provider. In this case, there was no public information on the rationale for contracting Elsevier's to provide "production, hosting, advertising and support" services for UNAM open access journals.

- Amounts of contracts between publicly-financed institutions and for-profit publishers should be published openly and publicly. This information becomes useful to take better, informed decisions regarding scholarly communication costs. In this case, both UNAM and Elsevier should have publicly and more widely informed the university community, and the general public, of the economic commitment by the UNAM under the contract in question, both as a total amount as well as disaggregated for each of the journals involved.

- In general specific contacts of journal managers in charge of journals should be clearly advertised on scholarly journals and platforms. In this case, the journal managers at Elsevier / ScienceDirect responsible for the migration, hosting, and maintenance of each of the ScienceDirect pages designated for the UNAM journals as detailed in the contract are unknown or the information is unclear.

- Whenever a contract is established between a publicly-financed institution and a third-party provider, a timeline for the completion of the contracted work should be publicly disclosed. In this case, a timeline for the migration of the production line and hosting of previous contents, including a detailed list of specific tasks of "advertising and support" should have been made public.

- Research data management (RDM), digital preservation and sustainability strategies and scholarly communication policies implicit in the clauses included in contracts should also be available to the public and key stakeholders. This is particularly important in relation to open access data management policy.

\section{Discussion}

We present the set of considerations above as instances of good practice regarding the handling of contracts between publicly-funded institutions and publishers. These considerations are shared in order to promote 
their discussion, adaptation, and implementation. If good practices regarding transparency and community participation in how institutional publishing contracts are handled are more widely and collaboratively discussed and developed, the national and international academic community would be able to follow in an informed, transparent, and expeditious manner the mechanisms for conducting contracts of public interest whose conditions have an effect on national and international academia, the public, and public intellectual heritage.

Writing a decade ago about intangible cultural heritage, Kurin had already warned that

Governments, or university departments or museums, cannot just assume that they have permission to define intangible cultural heritage and undertake its documentation, presentation, protection, or preservation. Community participation is meant to be significant and meaningful involving the consent of community leaders, consultation with lead cultural practitioners, shared decision making on strategies and tactics of safeguarding and so on (Kurin 2007).

The academic production of National Universities funded with public funds is an important component of a country's tangible and intangible cultural heritage. Digitisation and use of third-party publishing platforms complicates notions of Intellectual Property ownership and it has practical and legal geopolitical implications (Hennessy 2012). Kurin's concept in relation to UNESCO's Convention for the Safeguarding of the Intangible Heritage (UNESCO 2003) finds echoes in Bosman et al's recent discussion of the scholarly commons as essentially bottom-up and participatory. The considerations we have presented above seek to complement these ongoing attempts to define collectively the principles of the scholarly commons, which "start from the vision that scholarly communication needs to be as open and participatory as possible" and that indeed, "a publisher would be considered any entity that makes scholarly objects available according to the principles of the commons" (Bosman et al 2017).

By not encouraging a wider public discussion on why a public national university with a legacy of experience in academic publishing would want to cede the production of 44 of their journals to a for-profit third-party, and by not enabling public access to the information detailing the cost to the university in question, this case enacted principles that stand in contradiction to evolving principles of the scholarly commons.

Publicly-funded knowledge is, indeed, a common good: researchers and publishers have a responsibility to the public to provide free access to these research products. Additionally, researchers have a responsibility to the public to conduct rigorous research that provides the best value for money, which will, in turn, earn public trust. Therefore, it is crucial that researchers, as key participants and stakeholders in scholarly communications, retain control over how their research is conducted and disseminated. If researchers and their institutions retain such control, they can act in the best interests of academia whose goal is to share knowledge, rather than in the best interests of publishers whose goal is to maximize profits (Logan 2017).

This control from researchers and their institutions over how they choose to disseminate and preserve their research outputs can be understood as an act of academic self-determination. The processes to gain such control should be open, inclusive, transparent and participatory. Scholarly publishing and academic self-

determination are interdependent and a crucial point of future debate for the future of university presses and Open Access worldwide.

\section{Note}

Colleagues wishing to add their signature to the original open letter that inspired this article can still do it at https://goo.gl/forms/ZL8QF3ZVT4p3KFNr2 (Various 2017). 


\section{References}

Alperin, J.P., et al. 2015. Open Access in Latin America: a paragon for the rest of the world [Originally published in the SPARC blog] [online]. SciELO in Perspective. Available from: http://blog.scielo.org/en/ 2015/08/18/open-access-in-latin-america-a-paragon-for-the-rest-of-the-world-originally-publishedin-the-sparc-blog/

Bosman, J., Bruno, I., Chapman, C., Greshake Tzovaras, B., Jacobs, N., Kramer, B., .. Veksler, L. 2017. The Scholarly Commons - principles and practices to guide research communication. Available at: https: //osf.io/6c2xt/.

Eve, M. 2016. Referring Elsevier/RELX to the Competition and Markets Authority. Martin Eve 3 December. Available at: https://www.martineve.com/2016/12/03/referring-elsevierrelx-to-the-competitionand-markets-authority/.

Fiormonte, D. 2017. Digital Humanities and the Geopolitics of Knowledge. Digital Studies/Le champ numérique, 7(1). Available at: https://doi.org/10.16995\%2Fdscn. 274.

Fiormonte, E. \& Priego, E., 2016. Knowledge Monopolies and Global Academic Publishing. The Winnower. Available at: https://doi.org/10.15200\%2Fwinn.147220.00404.

Graham, et al, M., 2011. Visualizing the uneven geographies of knowledge production and circulation. Global Higher Education, 14.9. Available at: https://globalhighered.wordpress . com/2011/09/14/visualizingthe-uneven-geographies-of-knowledge-production-and-circulation/.

Hathcock, A., 2016. Making the Local Global: The Colonialism of Scholarly Communication. At the Intersection. Available at: https://aprilhathcock. wordpress.com/2016/09/27/making-the-local-globalthe-colonialism-of-scholarly-communication/.

Hennessy, K., 2012. From Intangible Expression to Digital Cultural Heritage (Chapter 3) - Safeguarding Intangible Cultural Heritage. In M. Stefano, P. Davis, \& G. Corsane (Eds.), Safeguarding Intangible Cultural Heritage (pp. 33-46).

Herrero Anzaldo, A.L., 2013. Iniciativa de Ley en México para el Acceso Abierto a resultados de investigaciones financiadas con fondos públicos. Available at: http://www.redalyc.org/redalyc/media/redalyc_ n/acceso-abierto/iniciativaOA_Mx.html.

i1706406, 2015. Contrato Elsevier UNAM. Available at: https://i1706406.wordpress.com/2015/11/30/ $3 /$.

Kurin, R., 2007. Safeguarding Intangible Cultural Heritage: Key Factors in Implementing the 2003 Convention. International Journal of Intangible Heritage, 2. Available at: http://pacificasiaobservatory . inclusivemuseum.org/files/2011/10/Kurin_IJIH-Vol2-1.pdf.

Lawson, S. \& Meghreblian, B., 2014. Journal subscription expenditure of UK higher education institutions. F1000Research. Available at: https://doi.org/10.12688\%2Ff1000research.5706.2.

Lawson, S., 2015. Financial transparency and the political influence of commercial publishing. The Winnower. Available at: https://doi.org/10.15200\%2Fwinn.143435.54519.

Logan, C.J., 2017. We can shift academic culture through publishing choices. F1000Research, 6. Available at: https://f1000research.com/articles/6-518/v2.

Posada, A. \& Chen, G., 2017. Publishers increasingly in control of scholarly infrastructure and this is why we should care. The Knowledge Gap: Geopolitics of Academic Production. Available at: http://knowledgegap. org/index.php/sub-projects/rent-seeking-and-financialization-of-the-academic-publishing-industry/ preliminary-findings/. 
Priego, E., 2017. Revistas académicas de la UNAM entregadas a Elsevier/ScienceDirect. Humanidades Digitales, 7.08. Available at: http://humanidadesdigitales.net/blog/2017/08/07/revistas-academicaselsevier-sciencedirect/.

Priego, E., 2017a. List of UNAM Journals Under Contract with Elsevier. figshare, https://doi.org/10. 6084/m9.figshare.3976752.v2. Available at: https ://figshare.com/articles/List_of_UNAM_Journals_ Under_Contract_with_Elsevier/3976752.

Priego, E., 2017b. Contrato UNAM-Elsevier: Resolución del Comité de Transparencia de la UNAM. Humanidades Digitales, 9.8. Available at: http://humanidadesdigitales.net/blog/2017/08/09/contratounam-elsevier-resolucion-del-comite-de-transparencia-de-la-unam/.

Rangel, R., 2014. Ley de Acceso Abierto en México: una crónica. Cuadernos Fronterizos, 38 (12). Available at: http://erevistas.uacj.mx/ojs/index.php/cuadfront/article/view/1407.

REDALyC, Colección institución - Universidad Nacional Autónoma de México. Available at: http://www . redalyc.org/institucion. oa?id=15992.

Schmitt, J., 2015. Can't Disrupt This: Elsevier and the 25.2 Billion Dollar A Year Academic Publishing Business. Medium, 22 December. Available at: https://medium.com/@jasonschmitt/can-t-disrupt-thiselsevier-and-the-25-2-billion-dollar-a-year-academic-publishing-business-aa3b9618d40a.

UNAM, 2017. Agenda Estadística UNAM 2016. Available at: http://www.planeacion.unam.mx/Agenda/ 2017/disco/.

UNAM, 2017. Portal de Estadísticas Universitarias. Available at: http://www.estadistica.unam.mx/numeralia

UNAM, Comité de Transparencia, 2016. Resolución CTR/49/2016. Available at: http://www . plataformatransparencia . unam.mx/archivos/repositorio/CT/2017/zip02ct/ctr-49-2016.pdf.

UNESCO, 2003. Text of the Convention for the Safeguarding of the Intangible Cultural Heritage - intangible heritage - Culture Sector - UNESCO. Available at: https://ich.unesco.org/en/convention.

UNESCO, 2017. Overview of OA in Latin America and the Caribbean | United Nations Educational, Scientific and Cultural Organization. Available at: http://www .unesco.org/new/en/communication-andinformation/portals-and-platforms/goap/access-by-region/latin-america-and-the-caribbean/.

Various, 2017. Carta abierta sobre contrato Elsevier - UNAM / Open Letter on the Elsevier - UNAM Contract

- Recolección de firmas/signature collection form. Available at: https://goo.gl/forms/ZL8QF3ZVT4p3KFNr2

Various, 2017. Carta abierta sobre contrato Elsevier - UNAM. Available at: https://goo.gl/dcbZnf. 